\title{
Covid-19: are we getting the communications right?
}

\author{
Other countries' experiences are instructive, says Andy Cowper
}

\author{
Andy Cowper editor \\ Health Policy Insight, London, UK
}

Handling the covid-19 epidemic requires a balanced approach that promptly tells people what they and the health system can do without causing panic. China, where the SARS-CoV-2 virus originally infected humans, tried to use an authoritarian approach to underplay the seriousness of the outbreak in its early stages. ${ }^{1}$ It is paradoxical therefore that China's aggressive approach to locking down cities is now credited with having slowed the epidemic's spread there. ${ }^{2}$

Iran is second to China in the covid-19 death toll to date. The country is also believed to have been less than candid about the situation there, a stance dramatically emphasised when its deputy health minister visibly succumbed to the illness during a televised press conference about the disease. ${ }^{3}$

In the UK, while the gravity of the situation has become clearer, the official communications response has been mixed. This patchiness has been exacerbated by the government's boycott of the national broadcast media outlets it considered "unfriendly" during last year's general election campaign. ${ }^{4}$ Thus we had the remarkable situation in which no minister was willing to appear on BBC Radio 4's agenda setting Today news programme to discuss preparations for dealing with covid-19. The former health secretary for England-and now health select committee chair-Jeremy Hunt was the only senior Tory willing to take part in the programme. His appearance generated approving responses from listeners and played a part in the government's decision to cancel its boycott of the programme, although this reversal of policy may be only temporary.

The government and the prime minister have also been criticised for being slow to respond. A tin ear with regard to the urgency of the situation was shown in the announcement that Boris Johnson would chair a meeting of the government's civil contingencies "COBRA" committee "after the weekend." Publication of the government's action plan followed on Tuesday 3 March. ${ }^{5}$ The was in stark contrast to the assured presentations given by England's chief medical officer, Chris Whitty, which included an excellent presentation to the Nuffield Trust's recent annual summit. ${ }^{6}$

\section{Role of experts}

It is interesting to observe the reactions of politicians and the national media to experts during a time of genuine and immediate risk to the public. Populism may have infected politics around the world, but its attractions seem limited in such a challenging situation. Cabinet Office minister Michael Gove's comment in 2016 that "I think the people in this country have had enough of experts" now seems remote from the current national mood in the UK.

Scientists, technocrats, and other experts could become the stars of 2020. The public's reaction to the communications efforts so far will be crucial to deciding how events proceed in the "contain" stage of the national strategy, which is to be followed by "delay spread," and then "do the science and research" and "mitigate impact on the NHS."

But, clearly, risks remain. The Daily Telegraph's respected Europe editor, Peter Foster, obtained an exclusive report on how 10 Downing Street had blocked health secretary Matt Hancock's attempt to keep the UK in the European Union's Early Warning and Response System (EWRS). ${ }^{8}$ The government did not deny this report.

There are causes for cheer in the early signs about public opinion. Pollster Ben Page of Ipsos MORI noted on Twitter that the UK was the country least satisfied with its government in research conducted last year. ${ }^{9}$ His firm's newly released research shows that $74 \%$ of a sample of over 1000 people in the UK support "the quarantine of cities and towns, preventing anyone from entering or leaving if there has been a large number of coronavirus cases there." 10

The poll's findings concerning the public's perception of the government response are less positive. The proportion of people in the sample who thought the government was doing a good job of containing the spread of the virus fell from $63 \%$ to $50 \%$ in the third week of February. In contrast, $70 \%$ of people believed that the UK's national health organisations were doing a good job, and 57\% thought that local health authorities and global health organisations were. 
Ipsos MORI's findings certainly suggest that, when it comes to covid-19 at least, the UK public hasn't "had enough of experts." And, however inept have been our politicians' communications and handling of covid-19 matters so far, we can draw strength from the fact the UK's leaders are performing better than US president Donald Trump. In a heroically confused live television meeting with drug company executives Trump failed to get executives to guarantee to him that the production of an effective vaccine for the disease was imminent. ${ }^{1}$

Provenance and peer review: Commissioned; not externally peer reviewed. Competing interests: None declared.

Kynge J, Yu S, Hancock T. Coronavirus: the cost of China's public health cover-up. Financial Times. Feb 2020. https://www.ft.com/content/fa83463a-4737-11ea-aeb3955839e06441.

2 Kupferschmidt K, Cohen J. China's aggressive measures have slowed the coronavirus. They may not work in other countries. Science. Mar 2020. https://www.sciencemag.org/ news/2020/03/china-s-aggressive-measures-have-slowed-coronavirus-they-may-notwork-other-countries

3 Turak N. Iranian deputy health minister, diagnosed with coronavirus, goes into quarantine as locals accuse Tehran of cover-up. CNBC. Feb 2020. https://www.cnbc.com/2020/02/ 26/iranian-health-minister-diagnosed-with-coronavirus-goes-into-quarantine-as-localsaccuse-tehran-of-cover-up.html

4 Honeycombe-Foster M. Boris Johnson urged to drop "childish" Today programme boycott as coronavirus crisis mounts. Feb 2020. https://www.politicshome.com/news/uk/politicalparties/conservative-party/news/110216/boris-johnson-urged-drop-childish-today.

5 Department of Health and Social Care. Coronavirus action plan. Mar 2020. https://www. gov.uk/government/publications/coronavirus-action-plan.

6 Summit 2020 session: Prof Chris Whitty on health trends and projections over the next 20 years. Nuffield Trust. Feb 2020. https://www.nuffieldtrust.org.uk/media/summit-2020session-prof-chris-whitty-on-the-direction-of-health-trends-over-the-next-20-years.

7 Sky News. Gove: Britons "have had enough of experts." YouTube. Jun 2016. https://www. youtube.com/watch?v=GGgiGtJk7MA.

8 Foster P. No 10 and Department of Health clash over access to EU pandemic warning system in wake of coronavirus. Telegraph. Mar 2020. https://www.telegraph.co.uk/politics/ 2020/03/01/downing-street-department-health-locked-row-access-eu-pandemic

9 Page B. Twitter. Mar 2020. https://twitter.com/benatipsosmori/status/ 1234419962053160960

10 Three-quarters of Britons support quarantining cities and towns to prevent the spread of coronavirus. Ipsos MORI. Mar 2020. https://www.ipsos.com/ipsos-mori/en-uk/threequarters-britons-support-quarantining-cities-and-towns-prevent-spread-coronavirus.

11 Benen S. Trump's confusion on display during meeting with pharmaceutical execs. https: //www.msnbc.com/rachel-maddow-show/trump-s-confusion-display-during-meetingpharmaceutical-execs-n1147766.

Published by the BMJ Publishing Group Limited. For permission to use (where not already granted under a licence) please go to http://group.bmj.com/group/rights-licensing/ permissions 